\title{
Effects of gamma irradiation on cytotoxicity and phenolic compounds of Thymus vulgaris L. and Mentha x piperita $\mathrm{L}$.
}

\author{
Eliana Pereira ${ }^{\text {a, b }}$, Andreia I. Pimenta ${ }^{c}$, Ricardo C. Calhelha ${ }^{a}$, Amilcar L. Antonio a \\ Sandra Cabo Verde ${ }^{c}$, Lillian Barros ${ }^{\mathrm{a}, \mathrm{d},{ }^{*} \text {, Celestino Santos-Buelga }}{ }^{\mathrm{b}}$, \\ Isabel C.F.R. Ferreira ${ }^{a}$,** \\ ${ }^{a}$ CIMO-Escola Superior Agrária, Instituto Politécnico de Bragança, Campus de Santa Apolónia, 1172, 5301-855 Bragança, Portugal \\ b GIP-USAL, Facultad de Farmacia, Universidad de Salamanca, Campus Miguel de Unamuno, 37007 Salamanca, Spain \\ ${ }^{c} C^{2} T N-$ Centro de Ciências e Tecnologias Nucleares, Instituto Superior Técnico, Universidade de Lisboa, Portugal \\ d Laboratory of Separation and Reaction Engineering (LSRE), Associate Laboratory LSRE/LCM, Polytechnic Institute of Bragança, Campus de Santa Apolónia, \\ 1134, 5301-857 Bragança, Portugal
}

\section{A R T I C L E I N F O}

\section{Article history:}

Received 12 January 2016

Received in revised form

1 April 2016

Accepted 2 April 2016

Available online 4 April 2016

\section{Keywords:}

Food irradiation

Cytotoxicity

Phenolic compounds

Aromatic herbs

\begin{abstract}
A B S T R A C T
The aim of the present study was to evaluate the effects of gamma irradiation on cytotoxicity and phenolic compounds of Thymus vulgaris L. and Menta $\times$ piperita L. (methanolic extracts), used in traditional medicine. Thirteen and fourteen phenolic compounds, including caffeoyl derivatives and flavonoid glycosides, were detected in T. vulgaris and Mentha piperita, respectively, none of which was affected by the irradiation dose used ( $10 \mathrm{kGy}$ ). Furthermore, the irradiation up to $10 \mathrm{kGy}$ did not change the cytotoxic properties of peppermint samples on tumor cell lines (MCF-7, NCI-H460, HeLa and HepG2), whereas thyme samples irradiated at $10 \mathrm{kGy}$ increased their cytotoxicity in the assayed tumor cell lines compared with samples submitted to 2 and $5 \mathrm{kGy}$. All in all, the dose of $10 \mathrm{kGy}$ was considered as suitable to be applied for the purpose of disinfestation and microbial decontamination of these plants without modifying their phenolic composition and bioactive properties.
\end{abstract}

() 2016 Elsevier Ltd. All rights reserved.

\section{Introduction}

Phytochemicals present in medicinal plants have revealed to be beneficial for the prevention of various diseases due to its capacity to act in multiple biological mechanisms (Zhang et al., 2011). Its antioxidant potential acts in the neutralization of reactive oxygen species (ROS) that cause damaging changes in the cells (Bajpai, Agrawal, Bang, \& Park, 2015; Jain, Jain, Jain, Jain, \& Balekar, 2010). The increasing interest in the use of phytochemicals is due to their natural origin, the possibility to be ingested through the diet, easy acquisition and also due to their reduced adverse effects (Dillard \& German, 2000). The use of medicinal plants for the treatment of different diseases dates back to ancient times, revealing satisfactory results as anti-inflammatory, antimicrobial, antimutagenic, anticancer and antioxidant agents.

\footnotetext{
* Corresponding author. CIMO-Escola Superior Agrária, Instituto Politécnico de Bragança, Campus de Santa Apolónia, 1172, 5301-855 Bragança, Portugal.

** Corresponding author. CIMO-Escola Superior Agrária, Instituto Politécnico de Bragança, Campus de Santa Apolónia, 1172, 5301-855 Bragança, Portugal.

E-mail addresses: lillian@ipb.pt (L. Barros), iferreira@ipb.pt (I.C.F.R. Ferreira).
}

These effects are in part explained by the presence of phytochemicals such as phenolic compounds (Wojdyło, Oszmiański, \& Czemerys, 2007).

Phenolic compounds are secondary metabolites ubiquitously distributed in plants (Jabri-Karoui, Bettaieb, Msaada, Hammami, \& Marzouk, 2012; Wojdyło et al., 2007). They include a large group of biologically active compounds, with over 8000 individual molecules described, having at least one aromatic ring with one or more hydroxyl groups attached, being able to vary from small molecules to large and complex ones. These compounds usually appear in their natural sources as esters and glycosides (Roby, Sarhan, Selim, \& Khalel, 2013; Vallverdú-Queralt et al., 2014).

Many species of plants recognized for their medicinal properties and beneficial impact on health contain these metabolites, such as e.g., Thymus vulgaris L. (thyme) and Mentha $\times$ piperita L. (peppermint) (Zgorka \& Glowniak, 2001; Kapp et al., 2013), belonging to the Lamiaceae family. Thyme is a plant widely used in folk medicine and its essential oil has shown bioactive properties because of its composition in bioactive metabolites (mixture of monoterpenes, being the main compounds thymol), such as antimicrobial, anti- 
inflammatory, expectorant, spasmolytic, antioxidant and hepatoprotective activities (Fecka \& Turek, 2008; Fachini-Queiroz et al. 2012; Martins et al., 2015; Nikolić et al., 2014; Gavarić et al., 2015). Similarly, peppermint is a perennial herb that is also commonly used in traditional medicine, mainly consumed as teas. It has been associated to antioxidant, antitumor, antimicrobial, hypoallergenic and immunomodulatory effects, as well as benefits for the digestive tract (Grigoleit \& Grigoleit, 2005; McKay \& Blumberg, 2006; Singh, Shushni, \& Belkheir, 2015). Its essential oil is also well known and widely used in food, pharmaceutical and cosmetic industries, because of presenting biological activity against several organisms (Moghaddam, Pourbaige, Tabar, Farhadi, \& Hosseini, 2013; Sharma \& Sharma, 2013).

The commercialization and use of medicinal plants must accomplish certain rules regarding to decontamination (Haleem, Salem, Fatahallah, \& Abdelfattah, 2015). Irradiation is increasingly recognized as a suitable approach to decontaminate natural matrices and preserve their components (Kume, Furuta, Todoriki, Uenoyama, \& Kobayashi, 2009). In particular, gamma irradiation was approved for disinfection and microbial control in various food products and supplements by the Food and Drug Administration (FDA), being a procedure technically and economically viable and physically safe with a powerful antimicrobial effect (Mizani, Sheikh, Ebrahimi, Gerami, \& Tavakoli, 2009). This decontamination method has interesting advantages that present it as a good alternative to other methods, namely for aromatic herbs (Pereira et al., 2015a). The majority of the studies with gamma irradiated herbs are related with the effects on nutritional composition and antioxidant properties. In this work we aimed at evaluating the effects on cytotoxicity and phenolic compounds using two Lamiaceae herbs (thyme and peppermint) as case-studies.

\section{Materials and methods}

\subsection{Herbs and samples irradiation}

Samples of $T$. vulgaris L. (thyme) and Mentha $\times$ piperita L. (peppermint) were provided as dry leaves by a local producer (Pragmático Aroma Lda, Alfândega da Fé, Bragança, Portugal). After confirmation of the taxonomical identification, the samples were divided into four groups: control (non-irradiated, $0 \mathrm{kGy}$ ), and samples irradiated with different doses (2, 5 and $10 \mathrm{kGy}$ ).

A Co-60 experimental chamber (Precisa 22, Graviner Manufacturing Company Ltd., UK) with total activity $140 \mathrm{TBq}$ (3.77 kCi), was used for sample irradiations, in May 2015. During the irradiation procedure, the dose and dose rate were estimated using a chemical solution sensitive to ionizing radiation, with an Amber Perspex dosimeters (Batch X, from Harwell Company, Didcot, Oxfordshire, UK), and a Fricke dosimeter, respectively (ASTM, 1992; Pereira et al., 2015a).

The estimated doses for thyme samples were $2.4 \pm 0.1 \mathrm{kGy}$, $5.5 \pm 0.2 \mathrm{kGy}$ and $10.4 \pm 0.5 \mathrm{kGy}$; and $2.2 \pm 0.3 \mathrm{kGy}, 5.7 \pm 0.21 \mathrm{kGy}$ and $10.3 \pm 0.4 \mathrm{kGy}$ for peppermint samples. The dose rates and dose uniformity ratios $\left(D_{\max } / D_{\min }\right)$ were, $1.2 \mathrm{kGy} / \mathrm{h}$ and 1.1 respectively. For simplicity, the values $0,2,5$ and $10 \mathrm{kGy}$ were considered for the doses of non-irradiated and irradiated groups, respectively.

\subsection{Standards and reagents}

Acetonitrile 99.9\% was of HPLC grade from Fisher Scientific (Lisbon, Portugal). Phenolic compound standards (apigenin-6-Cglucoside, caffeic acid, chlorogenic acid, hesperetin, luteolin-7-Oglucoside, naringenin, quercetin-3-O-rutinoside and rosmarinic acid) were from Extrasynthese (Genay, France). Fetal bovine serum (FBS), L-glutamine, Hank's balanced salt solution (HBSS), trypsin-
EDTA (ethylenediaminetetraacetic acid), penicillin/streptomycin solution (100 U/mL and $100 \mathrm{mg} / \mathrm{mL}$, respectively), RPMI-1640 and DMEM media were from Hyclone (Logan, UT, USA). Acetic acid, formic acid, ellipticine, sulforhodamine B (SRB), trypan blue, trichloroacetic acid (TCA) and Tris were from Sigma Chemical Co. (St. Louis, MO, USA). Water was treated in Milli-Q water purification system (TGI Pure Water Systems, Greenville, SC, USA). Ferrous ammonium sulfate(II) hexahydrate, sodium chloride and sulfuric acid, all with PA purity, were purchased from Panreac S.A. (Barcelona, Spain) (proanalysis), in order to prepare the acid aqueous Fricke dosimeter solution.

\subsection{Preparation of the extracts}

The dried samples of $T$. vulgaris and Mentha $\times$ piperita were reduced to a fine dried powder ( 20 mesh) and mixed to obtain homogeneity. To prepare the methanolic extracts, each sample ( $1 \mathrm{~g}$ ) was extracted by stirring with $25 \mathrm{~mL}$ of methanol $\left(25{ }^{\circ} \mathrm{C}\right.$ at $150 \mathrm{rpm}$ ) for $1 \mathrm{~h}$ and then filtered through Whatman No. 4 paper. The residue was then extracted with an additional portion of $25 \mathrm{~mL}$ of methanol $\left(25^{\circ} \mathrm{C}\right.$ at $\left.150 \mathrm{rpm}\right)$ for another $1 \mathrm{~h}$. Subsequently, the combined extracts were evaporated at $40{ }^{\circ} \mathrm{C}$ (rotary evaporator Büchi R-210, Flawil, Switzerland) until dryness.

\subsection{Evaluation of cytotoxic properties}

\subsubsection{General}

For cytotoxicity evaluation the extracts were redissolved in water, with a final solution of $8 \mathrm{mg} / \mathrm{mL}$ and diluted to different concentrations, and ellipticine was used as positive control. The results were calculated as $\mathrm{GI}_{50}$ values (sample concentration that inhibited $50 \%$ of the net cell growth).

\subsubsection{In tumor cell lines}

The human tumor cell lines used were: HeLa (cervical carcinoma), HepG2 (hepatocellular carcinoma), MCF-7 (breast adenocarcinoma) and $\mathrm{NCI}-\mathrm{H} 460$ (non-small cell lung cancer). Each of the cell lines were plated in a 96-well plate, at an appropriate density $\left(7.5 \times 10^{3}\right.$ cells/well for MCF-7 and NCI-H460 and $1.0 \times 10^{4}$ cells/ well for HeLa and HepG2) and were allowed to attach for $24 \mathrm{~h}$. Afterwards, various extract concentrations were added to the cells and incubated during $48 \mathrm{~h}$. Afterwards, cold trichloroacetic acid (TCA $10 \%, 100 \mu \mathrm{L}$ ) was used in order to bind the adherent cells and further incubated for $60 \mathrm{~min}$ at $4{ }^{\circ} \mathrm{C}$. After the incubation period, the plates were washed with deionised water and dried and sulforhodamine B solution (SRB $0.1 \%$ in $1 \%$ acetic acid, $100 \mu \mathrm{L}$ ) was then added to each plate well and incubated for $30 \mathrm{~min}$ at room temperature. The plates were washed with acetic acid (1\%) in order to remove the unbound SRB and air dried, the bounded SRB was solubilised with Tris $(10 \mathrm{mM}, 200 \mu \mathrm{L})$ and the absorbance was measured at $540 \mathrm{~nm}$ using an ELX800 microplate reader (Bio-Tek Instruments, Inc; Winooski, VT, USA) (Guimarães et al., 2013).

\subsubsection{In non-tumor cells}

A freshly harvested porcine liver, obtained from a local slaughter house, was used in order to obtain the cell culture, designated as PLP2. The liver tissues were rinsed in Hank's balanced salt solution containing penicillin $(100 \mathrm{U} / \mathrm{mL})$, streptomycin $(100 \mu \mathrm{g} / \mathrm{mL})$ and divided into $1 \times 1 \mathrm{~mm}^{3}$ explants. A few of these explants were transferred to a tissue flasks $\left(25 \mathrm{~cm}^{2}\right)$ containing DMEM medium supplemented with fetal bovine serum (FBS, 10\%), nonessential amino acids $(2 \mathrm{mM})$, penicillin $(100 \mathrm{U} / \mathrm{mL})$ and streptomycin $(100 \mathrm{mg} / \mathrm{mL})$ and incubated at $37^{\circ} \mathrm{C}$ with a humidified atmosphere $\left(5 \% \mathrm{CO}_{2}\right)$. The medium was changed every two days and the cell cultivation was continuously monitored using a phase contrast 
microscope. When confluence was reached, the cells were subcultured and plated in 96-well plate (density of $1.0 \times 10^{4}$ cells/ well) containing DMEM medium supplemented with FBS (10\%), penicillin $(100 \mathrm{U} / \mathrm{mL})$ and streptomycin $(100 \mu \mathrm{g} / \mathrm{mL})$. The growth inhibition was evaluated using the SRB assay, previously described (Guimarães et al., 2013).

\subsection{Analysis of phenolic compounds}

The extracts obtained above were analysed using a HPLC chromatograph (Hewlett-Packard 1100, Agilent Technologies, Santa Clara, CA, US) with a double online detection using a diode array detector (DAD) with 280, 330 and $370 \mathrm{~nm}$ as preference wavelengths, and a mass spectrometer (MS) equipped with an ESI source and a triple quadrupole-ion trap mass analyser, which was connected to the HPLC system via the DAD cell outlet (Barros et al., 2013). The DAD was coupled to an HP Chem Station (rev. A.05.04) and the MS was controlled by the Analyst 5.1 software. The separation was achieved using a Spherisorb S3 ODS-2 $C_{18}$ column $(3 \mu \mathrm{m}$, $4.6 \times 150 \mathrm{~mm}$ ) thermostatted at $35^{\circ} \mathrm{C}$, using a gradient elution with the following solvents: $0.1 \%$ formic acid in water (A) and acetonitrile (B). The elution gradient established was $15 \%$ B for 5 min, 15\% B to $20 \%$ B over $5 \mathrm{~min}, 20-25 \%$ B over $10 \mathrm{~min}, 25-35 \%$ B over $10 \mathrm{~min}$, $35-50 \%$ B for $10 \mathrm{~min}$, and re-equilibration of the column (10 $\mathrm{min})$, using a flow rate of $0.5 \mathrm{~mL} / \mathrm{min}$. The MS detector was programmed for recording in two consecutive modes: Enhanced MS (EMS), employed to show full scan spectra, and enhanced product ion (EPI) analysis. Air (zero graded) was used as the nebulizer gas (30 psi) and turbo gas for solvent drying $\left(400{ }^{\circ} \mathrm{C}, 40 \mathrm{psi}\right)$. Nitrogen functioned as the curtain (20 psi) and collision gas (medium). The ion spray voltage was set at $-4500 \mathrm{~V}$ and spectras were recorded in negative ion mode between $\mathrm{m} / \mathrm{z} 100$ and 1700 . The settings used were: declustering potential (DP) $-450 \mathrm{~V}$, entrance potential (EP) $-6 \mathrm{~V}$, collision energy (CE) $-10 \mathrm{~V}$. EPI mode was performed in order to obtain the fragmentation pattern of the parent ion(s) in the previous scan using the following parameters: DP $-50 \mathrm{~V}, \mathrm{EP}-6 \mathrm{~V}$, $\mathrm{CE}-25 \mathrm{~V}$, and collision energy spread (CES) $0 \mathrm{~V}$. Compounds were tentatively identified comparing the obtained information (retention times, UV-vis and mass spectra) with available data reported in the literature and by comparison with standard compounds, when available. For the quantification a calibration curve for each available phenolic standard (apigenin-6-C-glucoside, caffeic acid, chlorogenic acid, hesperetin, luteolin-7-O-glucoside, naringenin, quercetin-3-O-rutinoside, rosmarinic acid) was constructed based on the UV signal (maximum absorption of each standard compound lambda max). For the identified phenolic compounds for which a commercial standard was not available, the quantification was performed through the calibration curve of another compound from the same phenolic group. The results were expressed as mg per $g$ of extract.

\subsection{Statistical analysis}

For each one of the species two samples were used and all the assays were carried out in triplicate. The results are expressed as mean values and standard deviation (SD). The results were analysed using one-way analysis of variance (ANOVA) followed by Tukey's HSD Test with $\alpha=0.05$. In the case of phenolic composition, a Student's $t$-test was used to determine the significant difference among two different samples, with $\alpha=0.05$. This analysis was carried out using IBM SPSS Statistics for Windows, Version 22.0. (IBM Corp., Armonk, New York, USA).

\section{Results and discussion}

\subsection{Cytotoxic properties of extracts from non-irradiated and irradiated samples}

The results obtained in the evaluation of the cytotoxic properties of thyme and peppermint (extracts prepared from nonirradiated and irradiated samples) against four human tumor cell lines (MCF-7, NCI-H460, HeLa and HepG2) and against non-tumor cells are given in Table 1. All samples showed cytotoxicity, and these results are in agreement with a previous study performed by Berdowska et al. (2013) that used dried aqueous extracts of T. vulgaris from Poland, reporting its cytotoxicity in MCF-7 (breast carcinoma) tumor cell line. Lv et al. (2012) also evaluated the antiproliferative activity of a peppermint extract against the human tumor cell line HT-29, describing promising results.

The thyme sample irradiated at $10 \mathrm{kGy}$ showed cytotoxicity for MCF-7, HeLa and HepG2 cell lines similar to the control sample, and higher (lower $\mathrm{GI}_{50}$ values) than the toxicity revealed by the samples irradiated at 2 and $5 \mathrm{kGy}$. Regarding peppermint, no significant differences were observed when different doses were applied, with the exception of MCF-7 cell line, where a higher cytotoxicity was observed in the control sample $(0 \mathrm{kGy})$. In relation to the toxicity for non-tumor cells, none of the samples presented hepatotoxicity $\left(\mathrm{GI}_{50}>400 \mu \mathrm{g} / \mathrm{mL}\right)$.

\subsection{Comparative analysis of the phenolic compounds in non- irradiated and irradiated samples}

As, in general, no significant differences were found in the cytotoxic properties of the extracts prepared from samples irradiated at three different doses (2, 5 and $10 \mathrm{kGy})$. Nonetheless, control samples and samples irradiated at the highest dose (10 kGy) were used for phenolic compounds analysis, due to the higher efficiency of higher doses in the decontamination process.

Thirteen and fourteen phenolic compounds were identified in the methanolic extracts of thyme and peppermint, respectively. Tables 2 and 3 present data related to the phenolic compounds identification (retention time, $\lambda_{\max }$ in the visible region, molecular ion, main fragment ions in $\mathrm{MS}^{2}$, tentative identification and quantification) obtained by HPLC-DAD-ESI/MS analysis for both species. Fig. 1 shows the phenolic compounds profile in thyme and peppermint, recorded at $280 \mathrm{~nm}$.

Compounds 2 (apigenin 6,8-di-C-glucoside), 3 (caffeic acid), 6 (rosmarinic acid hexoside), 7 (luteolin-7-O-glucuronide), 8 (luteolin-7-O-glucoside), 10 (rosmarinic acid), 12 (lithospermic acid A) and 13 (eriodictyol) in thyme were already described and tentatively identified in a previous study carried out by our research group, but using a different commercial sample (Martins et al., 2015). Moreover, the majority of the mentioned compounds have been previously cited in thyme samples (Boros et al., 2010; Costa et al., 2012; Dapkevicius et al., 2002; Fecka \& Turek, 2008; Hossain, Rai, Brunton, Martin-Diana, \& Barry-ryan, 2010; Roby et al., 2013; Vallverdú-Queralt et al., 2014; Vergara-Salinas, PerezJiménez, Torres, Agosin \& Pérez-Correa, 2012). Compounds 1, 4, 5, 9 and 11 were not described in our previous study (Martins et al., 2015), which may be due to the existence of different composition and/or distribution of phenolic compounds depending on the part tissue, the origin of the plant and the edaphoclimatic conditions (Boros et al., 2010; Costa et al., 2012). Based on their UV and mass spectra, compounds were tentatively identified as caffeic acid hexoside (peak 1 ), methyleriodictyol $O$-pentosylhexoside (peak 4) and quercetin- $O$-glucuronide (peak 5). Peak $9\left([\mathrm{M}-\mathrm{H}]^{-}\right.$at $m / z$ 537) showed similar UV and mass spectra characteristics as lithospermic acid $A$ (peak 12), although it was eluted at a different retention 
Table 1

Cytotoxicity of thyme and peppermint extracts prepared from non-irradiated and irradiated samples.

\begin{tabular}{|c|c|c|c|c|}
\hline & \multicolumn{4}{|l|}{ Doses } \\
\hline & $0 \mathrm{kGy}$ & 2 kGy & $5 \mathrm{kGy}$ & 10 kGy \\
\hline \multicolumn{5}{|l|}{ Thyme } \\
\hline MCF-7 (breast carcinoma) & $88 \pm 7^{\mathrm{b}}$ & $104 \pm 6^{\mathrm{a}}$ & $106 \pm 10^{\mathrm{a}}$ & $83 \pm 9^{b}$ \\
\hline NCI-H460 (non-small cell lung cancer) & $294 \pm 12^{\mathrm{a}}$ & $276 \pm 16^{\mathrm{ab}}$ & $297 \pm 11^{\mathrm{a}}$ & $262 \pm 4^{b}$ \\
\hline HeLa (cervical carcinoma) & $161 \pm 6^{b}$ & $189 \pm 13^{\mathrm{a}}$ & $191 \pm 9^{a}$ & $160 \pm 13^{b}$ \\
\hline HepG2 (hepatocellular carcinoma) & $103 \pm 10^{\mathrm{a}}$ & $110 \pm 13^{\mathrm{a}}$ & $106 \pm 8^{\mathrm{a}}$ & $100 \pm 10^{\mathrm{a}}$ \\
\hline Hepatotoxicity PLP2 (non-tumor cells) & $>400$ & $>400$ & $>400$ & $>400$ \\
\hline \multicolumn{5}{|l|}{ Peppermint } \\
\hline MCF-7 (breast carcinoma) & $114 \pm 12^{\mathrm{b}}$ & $175 \pm 15^{\mathrm{a}}$ & $150 \pm 4^{\mathrm{ab}}$ & $154 \pm 7^{\mathrm{ab}}$ \\
\hline NCI-H460 (non-small cell lung cancer) & $226 \pm 11^{\mathrm{a}}$ & $224 \pm 2^{\mathrm{a}}$ & $213 \pm 20^{\mathrm{a}}$ & $229 \pm 16^{\mathrm{a}}$ \\
\hline HeLa (cervical carcinoma) & $221 \pm 13^{a}$ & $206 \pm 11^{\mathrm{a}}$ & $211 \pm 21^{\mathrm{a}}$ & $214 \pm 12^{\mathrm{a}}$ \\
\hline HepG2 (hepatocellular carcinoma) & $98 \pm 9^{a}$ & $115 \pm 9^{a}$ & $106 \pm 11^{\mathrm{a}}$ & $111 \pm 12^{\mathrm{a}}$ \\
\hline Hepatotoxicity PLP2 (non-tumor cells) & $>400$ & $>400$ & $>400$ & $>400$ \\
\hline
\end{tabular}

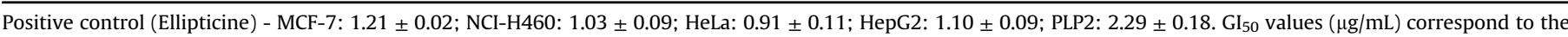

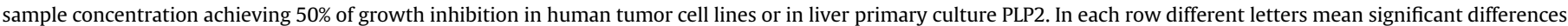
$(\mathrm{p}<0.05)$

Table 2

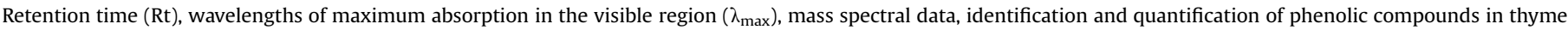
extracts prepared from non-irradiated and irradiated samples (mg/g extract).

\begin{tabular}{|c|c|c|c|c|c|c|c|c|c|}
\hline \multirow[t]{2}{*}{ Peak } & \multirow{2}{*}{$\begin{array}{l}\text { Rt } \\
(\mathrm{min})\end{array}$} & \multirow{2}{*}{$\lambda_{\max }(\mathrm{nm})$} & \multirow{2}{*}{$\begin{array}{l}\text { Molecular ion } \\
{[\mathrm{M}-\mathrm{H}]^{-}(m / z)}\end{array}$} & \multirow[t]{2}{*}{$\operatorname{MS}^{2}(m / z)$} & \multirow{2}{*}{$\begin{array}{l}\text { Tentative } \\
\text { identification }\end{array}$} & \multirow{2}{*}{$\begin{array}{l}\text { Type of } \\
\text { identification }\end{array}$} & \multicolumn{2}{|c|}{ Quantification (mg/g) } & \multirow{2}{*}{$\begin{array}{l}t \text {-Students } \\
\text { test } p \text {-value }\end{array}$} \\
\hline & & & & & & & 0 kGy & 10 kGy & \\
\hline 1 & 7.3 & 320 & 341 & $179(100), 135(88)$ & Caffeic acid hexoside & $\begin{array}{l}\text { References } \\
1,2,3,4 / \mathrm{DAD} / \mathrm{MS}\end{array}$ & $1.7 \pm 0.1$ & $1.5 \pm 0.1$ & 0.988 \\
\hline 2 & 10.8 & 338 & 593 & 473(20),383(33),353(27),297(5) & $\begin{array}{l}\text { Apigenin } 6,8 \text {-di-C- } \\
\text { glucoside }\end{array}$ & $\begin{array}{l}\text { Reference } 5 / \\
\text { DAD/MS }\end{array}$ & $3.45 \pm 0.04$ & $3.31 \pm 0.04$ & 0.212 \\
\hline 3 & 11.3 & 326 & 179 & $135(100)$ & Caffeic acid & $\begin{array}{l}\text { Reference 5/ } \\
\text { Standard/DAD/ } \\
\text { MS }\end{array}$ & $2.69 \pm 0.01$ & $2.5 \pm 0.4$ & 0.258 \\
\hline 4 & 17.4 & $284,336 \mathrm{sh}$ & 595 & $301(47), 286(100)$ & $\begin{array}{l}\text { Methyleriodictyol-O- } \\
\text { pentosylhexoside }\end{array}$ & $\mathrm{DAD} / \mathrm{MS}$ & $3.12 \pm 0.01$ & $1.9 \pm 0.4$ & 0.005 \\
\hline 5 & 18.1 & 350 & 461 & $301(100)$ & $\begin{array}{l}\text { Quercetin-O- } \\
\text { glucuronide }\end{array}$ & $\mathrm{DAD} / \mathrm{MS}$ & $0.4 \pm 0.1$ & $0.35 \pm 0.03$ & 0.742 \\
\hline 6 & 18.8 & 322 & 521 & 359(100),197(13),179(36),161(62),135(21) & $\begin{array}{l}\text { Rosmarinic acid } \\
\text { hexoside }\end{array}$ & $\begin{array}{l}\text { Reference } 5 / \\
\text { DAD/MS }\end{array}$ & $16.8 \pm 0.1$ & $14.7 \pm 0.2$ & 0.378 \\
\hline 7 & 20.0 & 348 & 461 & $285(100)$ & $\begin{array}{l}\text { Luteolin-7-O- } \\
\text { glucuronide }\end{array}$ & $\begin{array}{l}\text { Reference 5/ } \\
\text { DAD/MS }\end{array}$ & $8.4 \pm 0.2$ & $7.1 \pm 0.2$ & 0.381 \\
\hline 8 & 20.8 & 350 & 447 & $285(100)$ & $\begin{array}{l}\text { Luteolin-7-O- } \\
\text { glucoside }\end{array}$ & $\begin{array}{l}\text { Reference 5/ } \\
\text { Standard/DAD/ } \\
\text { MS }\end{array}$ & $3.34 \pm 0.01$ & $3.2 \pm 0.1$ & 0.003 \\
\hline 9 & 23.4 & 286,320 sh & 537 & $\begin{array}{l}\text { 493(20),359(70),295(5),197(13),179(28),161(100), } \\
\text { 135(63) }\end{array}$ & Caffeic acid trimer & $\mathrm{DAD} / \mathrm{MS}$ & $9.1 \pm 0.1$ & $8.0 \pm 0.1$ & 0.027 \\
\hline 10 & 24.0 & 330 & 359 & $197(17), 179(35), 161(100), 135(29)$ & Rosmarinic acid & $\begin{array}{l}\text { Reference 5/ } \\
\text { Standard/DAD/ } \\
\text { MS }\end{array}$ & $12.7 \pm 0.4$ & $10.4 \pm 0.2$ & 0.038 \\
\hline 11 & 25.6 & 282 & 567 & $535(23), 493(49), 387(32), 285(25), 197(13)$ & $\begin{array}{l}\text { Caffeic acid } \\
\text { derivative }\end{array}$ & $\mathrm{DAD} / \mathrm{MS}$ & $2.3 \pm 0.1$ & $1.68 \pm 0.05$ & 0.001 \\
\hline 12 & 27.5 & $290,326 \mathrm{sh}$ & 537 & 493(50),359(17),295(33),179(75),135(100) & Lithospermic acid A & $\begin{array}{l}\text { Reference } 5 / \\
\text { DAD/MS }\end{array}$ & $2.25 \pm 0.01$ & $1.9 \pm 0.1$ & 0.999 \\
\hline \multirow[t]{4}{*}{13} & 30.6 & 288,334 sh & 287 & 151(35),135(100) & Eriodictyol & $\begin{array}{l}\text { Reference 5/ } \\
\text { Standard/DAD/ } \\
\text { MS }\end{array}$ & $0.87 \pm 0.01$ & $0.53 \pm 0.04$ & 0.001 \\
\hline & & & & & Total phenolic acids & & $48 \pm 1$ & $47 \pm 1$ & 0.251 \\
\hline & & & & & Total flavonoids & & $19.5 \pm 0.3$ & $19.0 \pm 0.1$ & 0.010 \\
\hline & & & & & $\begin{array}{l}\text { Total phenolic } \\
\text { compounds }\end{array}$ & & $67 \pm 1$ & $66 \pm 1$ & 0.097 \\
\hline
\end{tabular}

References: (1) Hossain et al. (2010); (2) Nagy et al. (2011); (3) Vergara-Salinas et al. (2012); (4) Vallverdú-Queralt et al. (2014); (5) Martins et al. (2015).

time. The presence of salvianolic acid I with the same molecular weight was reported in thyme by Dapkevicius et al. (2002) and Nagy, Solar, Sontag, and Koenig (2011), although no sufficient elements for assigning that identity to the compound detected herein, so that the compound was just identified as a caffeic acid trimer. Compound $11\left([\mathrm{M}-\mathrm{H}]^{-}\right.$at $m / z$ 567) should also correspond to a caffeic acid derivative, owing to its UV spectrum and the observation of an $M S^{2}$ fragments at $m / z 493$, coherent with salvianolic acid A, furthermore, the fragment at $m / z 197$ could be attributed to dihydroxyphenyl-lactic acid (danshensu); however, no definite structure could be matched for the compound, so that it remains as an unidentified caffeic acid derivative. The presence of caffeic acid 
Table 3

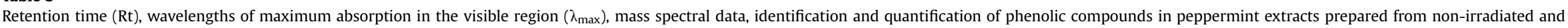
irradiated samples (mg/g extract).

\begin{tabular}{|c|c|c|c|c|c|c|c|c|c|}
\hline \multirow[t]{2}{*}{ Peak } & \multirow{2}{*}{$\begin{array}{l}\mathrm{Rt} \\
(\min )\end{array}$} & \multirow{2}{*}{$\lambda_{\max }(\mathrm{nm})$} & \multirow{2}{*}{$\begin{array}{l}\text { Molecular ion } \\
{[\mathrm{M}-\mathrm{H}]^{-}(m / z)}\end{array}$} & \multirow[t]{2}{*}{$\operatorname{MS}^{2}(m / z)$} & \multirow{2}{*}{$\begin{array}{l}\text { Tentative } \\
\text { identification }\end{array}$} & \multirow[t]{2}{*}{ Type of identification } & \multicolumn{2}{|c|}{ Quantification (mg/g) } & \multirow{2}{*}{$\begin{array}{l}t \text {-Students test } \\
p \text {-value }\end{array}$} \\
\hline & & & & & & & $0 \mathrm{kGy}$ & $10 \mathrm{kGy}$ & \\
\hline $1^{\prime}$ & 5.1 & 328 & 353 & 191(100),179(27),173(5),161(15),135(30) & $\begin{array}{l}\text { 3-O- } \\
\text { Caffeoylquinic } \\
\text { acid }\end{array}$ & Reference 1/DAD/MS & $0.87 \pm 0.02$ & $0.76 \pm 0.01$ & 0.001 \\
\hline $2^{\prime}$ & 7.1 & 328 & 353 & 191(100),179(90),173(50),161(20),135(57) & $\begin{array}{l}\text { 5-O- } \\
\text { Caffeoylquinic } \\
\text { acid }\end{array}$ & $\begin{array}{l}\text { References 2,3/ } \\
\text { Standard/DAD/MS }\end{array}$ & $1.4 \pm 0.1$ & $1.2 \pm 0.1$ & 0.025 \\
\hline $3^{\prime}$ & 11.1 & 326 & 179 & 135(100) & Caffeic acid & $\begin{array}{l}\text { References 2,3,4,5/ } \\
\text { Standard/DAD/MS }\end{array}$ & $0.44 \pm 0.01$ & $0.5 \pm 0.1$ & 0.134 \\
\hline $4^{\prime}$ & 14.5 & 348 & 637 & $285(100)$ & $\begin{array}{l}\text { Luteolin- } O- \\
\text { diglucuronide }\end{array}$ & $\begin{array}{l}\text { References 2,3,7/DAD/ } \\
\text { MS }\end{array}$ & $7.1 \pm 0.2$ & $6.22 \pm 0.01$ & 0.001 \\
\hline $5^{\prime}$ & 15.7 & 288,330 sh & 537 & 493(45),313(18),295(36),269(55),197(36),179(64),135(100) & $\begin{array}{l}\text { Caffeic acid } \\
\text { trimer }\end{array}$ & $\mathrm{DAD} / \mathrm{MS}$ & $3.1 \pm 0.2$ & $2.9 \pm 0.2$ & 0.115 \\
\hline $6^{\prime}$ & 16.1 & 284,332sh & 595 & $287(100)$ & $\begin{array}{l}\text { Eriodictyol-O- } \\
\text { rutinoside }\end{array}$ & References 3,7/DAD/MS & $100 \pm 1$ & $102.47 \pm 0.01$ & 0.005 \\
\hline $7^{\prime}$ & 17.1 & 286,336 sh & 449 & $287(100)$ & $\begin{array}{l}\text { Eriodictyol-O- } \\
\text { hexoside }\end{array}$ & DAD/MS & $2.2 \pm 0.2$ & $2.1 \pm 0.1$ & 0.157 \\
\hline $8^{\prime}$ & 19.0 & 350 & 593 & $285(100)$ & $\begin{array}{l}\text { Luteolin-7-O- } \\
\text { rutinoside }\end{array}$ & $\begin{array}{l}\text { References 2,3,6/ } \\
\text { Standard/DAD/MS }\end{array}$ & $30.2 \pm 0.1$ & $30.3 \pm 0.6$ & 0.677 \\
\hline $9^{\prime}$ & 19.8 & 348 & 461 & $285(100)$ & $\begin{array}{l}\text { Luteolin-7-O- } \\
\text { glucuronide }\end{array}$ & $\begin{array}{l}\text { References 2,3,7/DAD/ } \\
\text { MS }\end{array}$ & $11.2 \pm 0.2$ & $10.0 \pm 0.4$ & 0.002 \\
\hline $10^{\prime}$ & 20.0 & 282,330sh & 579 & $271(100)$ & $\begin{array}{l}\text { Naringenin- } O- \\
\text { rutinoside }\end{array}$ & References 2,3/DAD/MS & $3.1 \pm 0.1$ & $3.0 \pm 0.2$ & 0.362 \\
\hline $11^{\prime}$ & 21.5 & 278,338 sh & 717 & 537(34),519(50),493(39),339(29),321(37),313(6),295(100),197(3),179(11),161(5),135(11) & $\begin{array}{l}\text { Salvianolic acid } \\
\text { B/E/L }\end{array}$ & References 2,3/DAD/MS & $13 \pm 1$ & $13.4 \pm 0.3$ & 0.276 \\
\hline $12^{\prime}$ & 22.6 & $286,338 \mathrm{sh}$ & 609 & $301(100)$ & $\begin{array}{l}\text { Hesperetin-O- } \\
\text { rutinoside }\end{array}$ & DAD/MS & $5.5 \pm 0.3$ & $5.6 \pm 0.2$ & 0.302 \\
\hline $13^{\prime}$ & 23.6 & 330 & 359 & 197(13),179(20),161(100),135(21) & Rosmarinic acid & $\begin{array}{l}\text { References 2,3,4,5/ } \\
\text { Standard/DAD/MS }\end{array}$ & $25 \pm 1$ & $25.1 \pm 0.1$ & 0.291 \\
\hline \multirow[t]{4}{*}{$14^{\prime}$} & 24.0 & 288,340 sh & 493 & $313(5), 295(100), 279(3), 197(14), 179(8), 135(5)$ & Salvianolic acid A & $\mathrm{DAD} / \mathrm{MS}$ & $10.3 \pm 0.5$ & $9.72 \pm 0.01$ & 0.065 \\
\hline & & & & & $\begin{array}{l}\text { Total phenolic } \\
\text { acids }\end{array}$ & & $53 \pm 3$ & $54 \pm 1$ & 0.939 \\
\hline & & & & & Total flavonoids & & $159 \pm 2$ & $159.7 \pm 0.1$ & 0.248 \\
\hline & & & & & $\begin{array}{l}\text { Total phenolic } \\
\text { compounds }\end{array}$ & & $212 \pm 4$ & $213.7 \pm 0.5$ & 0.607 \\
\hline
\end{tabular}



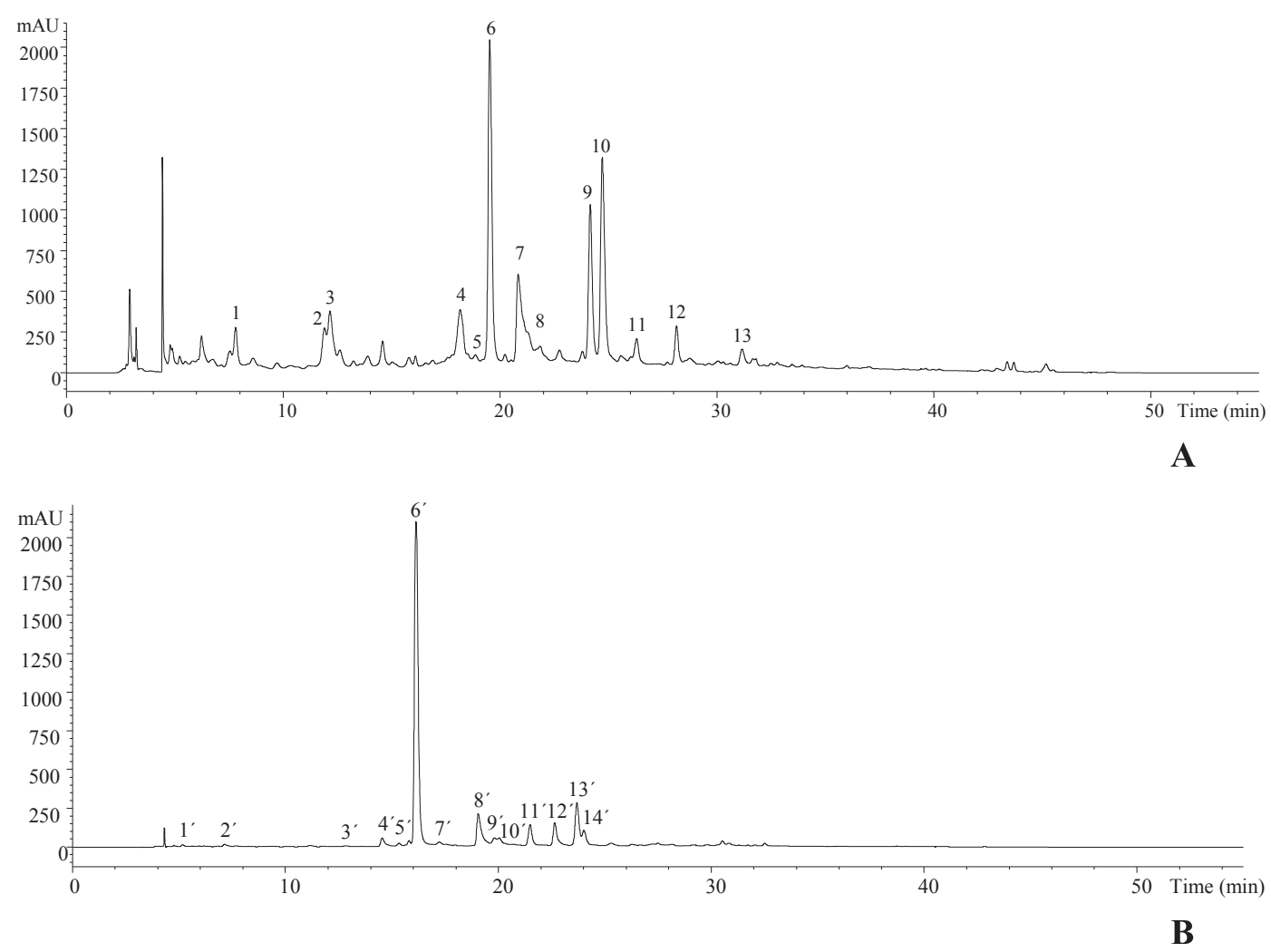

Fig. 1. Individual profile of thyme (A) and peppermint (B) irradiated with $10 \mathrm{kGy}$ recorded at 280.

hexoside has been already reported in thyme by Hossain et al. (2010), Nagy et al. (2011), Vergara-Salinas et al. (2012) and Vallverdú-Queralt et al. (2014). To the best of our knowledge the other three compounds tentatively identified herein have not been previously cited in T. vulgaris.

Regarding peppermint, caffeic acid (compound $3^{\prime}$ ), chlorogenic acid (i.e., 5-O-caffeoylquinic acid; compound $2^{\prime}$ ), luteolin-7-Orutinoside (compound $8^{\prime}$ ) and rosmarinic acid (compound 13') were positively identified according to their retention, mass spectra and UV-vis characteristics in comparison with commercial standards. These compounds were also described in Mentha piperita leaves (using petroleum ether, chloroform, ethyl ether, ethyl acetate, acetone, methanol, ethanol, ethanol $80 \%$ and ethanol $30 \%$ and a boiling water extract) of commercial and non-commercial samples (Areias, Valentão, Andrade, Ferreres, \& Seabra, 2001), in M. piperita infusions (Kapp et al., 2013; Pérez, Rocha-Guzmán, Mercado-Silva, Loarca-Piña, \& Reynoso-Camacho, 2014), in extracts from conventional and organically grown peppermint samples (soluble free phenolics, soluble conjugated phenolics, insoluble bound phenolics) (Lv et al., 2012) and in a revision of the literature performed by Riachi and De Maria (2015).

Compound $1^{\prime}$ was identified as 3-O-caffeoylquinic acid based on its MS $^{2}$ fragmentation, yielding the base peak at $m / z 191$ and the ion at $\mathrm{m} / \mathrm{z} 179$ with an intensity of $72 \%$ relative to the base peak, considered characteristic of 3-acylchlorogenic acids as reported by Clifford, Johnston, Knight, and Kuhnert (2003). The sample also presented other caffeic acid derivatives, namely compounds $5^{\prime}, 11^{\prime}$ and $14^{\prime}$. The pseudomolecular ion $\left([\mathrm{M}-\mathrm{H}]^{-}\right.$at $\left.m / z 537\right)$ and fragmentation pattern of peak $5^{\prime}$ were consistent with a caffeic acid trimer, although it eluted at an earlier retention time than lithospermic acid A. As above discussed for peak 9 in the thyme sample (Table 2), besides lithospermic acid $A$, the molecular weight of the compound would also match that of salvianolic acid H/I, reported by Kapp et al. (2013) in peppermint teas, although no further support for that identity could be obtained, so that in our case the compound has been just assigned as a caffeic acid trimer. The molecular weight of compound $14^{\prime}\left([\mathrm{M}-\mathrm{H}]^{-}\right.$at $m / z$ 493, compound $14^{\prime}$ ) might correspond to salvianolic acid $A$, whereas that of compound $11^{\prime}\left([\mathrm{M}-\mathrm{H}]^{-}\right.$at $\mathrm{m} / \mathrm{z}$ 717) might correspond to salvianolic acids $\mathrm{B}$ or $\mathrm{E}$, whose presence was reported in peppermint teas by Kapp et al. (2013), or salvianolic acid L, cited by Krzyzanowska, Janda, Pecio, Stochmal, and Oleszek (2011) in the aerial parts of Mentha species. Similar caffeoyl derivatives have been cited in mentha samples by other authors as reviewed by Riachi and De Maria (2015). All these compounds were quantified based on caffeic and rosmarinic acid calibration curves.

The remaining compounds were identified as flavonoids. Peaks $4^{\prime}\left([\mathrm{M}-\mathrm{H}]^{-}\right.$at $m / z$ 637) and $9^{\prime}\left([\mathrm{M}-\mathrm{H}]^{-}\right.$at $m / z$ 461) were assigned as luteolin glycosides, based on their UV spectra $\left(\lambda_{\max }\right.$ around $350 \mathrm{~nm}$ ) and the production of an $\mathrm{MS}^{2}$ fragment ion at $m / z 285$. Compound $9^{\prime}$ can be assumed as luteolin-7-O-glucuronide by comparison with a commercial standard, whereas compound $4^{\prime}$ was tentatively assigned as luteolin- $O$-diglucuronide. The presence of luteolin glucuronides in M. piperita samples was also reported by Krzyzanowska et al. (2011), Kapp et al. (2013) and Riachi and De Maria (2015). Compounds $6^{\prime}\left([\mathrm{M}-\mathrm{H}]^{-}\right.$at $m / z$ 595) and $7^{\prime}$ $\left([\mathrm{M}-\mathrm{H}]^{-}\right.$at $\left.m / z 449\right)$ were tentatively identified as eriodictyol-Orutinoside and eriodictyol- $O$-hexoside, respectively, previously described in M. piperita by Krzyzanowska et al. (2011) and Riachi and De Maria (2015). Based on the mass spectra, compounds $10^{\prime}$ $\left([\mathrm{M}-\mathrm{H}]^{-}\right.$at $\left.m / z 579\right)$ and $12^{\prime}\left([\mathrm{M}-\mathrm{H}]^{-}\right.$at $\left.m / z 609\right)$ were identified as rutinosyl derivatives of the flavanones naringenin and hesperetin, respectively. The presence of narirutin (i.e., naringenin-7-Orutinoside) in peppermint samples was cited by Kapp et al. (2013) and Riachi and De Maria (2015).

In a previous study rosmarinic acid and luteolin-7-O- 
glucuronide were found as the most abundant compounds in thyme (Martins et al., 2015). These compounds were also relevant components in the sample analysed herein, although in this case rosmarinic acid hexoside appeared as the most abundant phenolic compound. These differences could be related with the natural variability inherent to plants grown under different environmental conditions that influence their secondary metabolism (Riachi \& De Maria, 2015). Eriodictyol-7-O-rutinoside was the most abundant compound in peppermint, in agreement with a previous study performed by Areias et al. (2001). The irradiation at $10 \mathrm{kGy}$ did not affect the phenolic composition in both plant samples in relation to non irradiated control samples, which could be explained by the reduced water activity of this matrix. The molecules preservation by irradiation mostly depends on the food composition in water content, temperature and the presence or absence of oxygen in the process, thus the dried food has a reduced effect of radiolytic products production (Sadecká, 2007). However, a different effect was observed in a study performed by Pereira et al. (2015b), where the irradiated sample at $10 \mathrm{kGy}$ showed the highest content in phenolic compounds. This could be explained by the usage of a high dose of radiation that leads to an increase in the extractability of certain phenolic compounds. Another reason that could justify this effect is the water activity that remains after the drying process. Thereby, Ginkgo biloba sample might have higher water content, which triggered a higher formation of radiolytic compounds, leading to the changes verified in the phenolic contents (TezottoUliana, Silva, Kluge, \& Spoto, 2015). Therefore, it can be concluded that gamma irradiation does not conduct to a linear behaviour towards the conservation of compounds in plants, and depends also on other factors (e.g., water composition, different compounds present in plants, dose applied). Nonetheless, this radiation dose could be recommended as adequate to decontaminate these plants without affecting their contents on phenolic compounds. The same dose was also recommended by Machhour, Hadrami, Imziln, Mouhib, and Mahrouz (2011) with similar purposes.

In order to correlate the sample's cytotoxic effects with the phenolic composition, correlation factors were obtained between total phenolic acids and total flavonoids, and the $\mathrm{GI}_{50}$ values obtained for the four cell lines. The results showed high correlations in both plant samples for three of the cell lines, with the exception of MCF-7, where no correlation was found between the total contents of these phenolic groups. Nevertheless, the thyme cytotoxic activity obtained in MCF-7 cell line was highly correlated with caffeic acid $\left(R^{2}=0.7100\right)$, caffeic acid trimer $\left(R^{2}=0.7709\right)$, methyleriodictyol$O$-pentosylhexoside $\left(R^{2}=0.4375\right)$, rosmarinic acid hexoside $\left(R^{2}=0.4247\right)$, luteolin-7-O-glucoside $\left(R^{2}=0.4305\right)$, and lithospermic acid A $\left(R^{2}=0.4272\right)$, while in peppermint the main contributor compounds were caffeic acid $\left(R^{2}=0.8586\right)$, caffeic acid trimer $\left(R^{2}=0.7667\right)$, luteolin-7-O-rutinoside $\left(R^{2}=0.6649\right)$ and luteolin-7-O-glucuronide $\left(R^{2}=0.6466\right)$.

The cytotoxic effects of thyme extracts for the other three cell lines, also presented high correlation factors, being $\mathrm{NCI}-\mathrm{H} 460$ cell line highly correlated with total flavonoids $\left(R^{2}=0.9991\right)$ and HeLa and HepG2 cell lines with total phenolic acids $\left(R^{2}=0.7483\right.$ and 0.8139 , respectively). The individual flavonoids that were highly correlated with $\mathrm{NCI}-\mathrm{H} 460$ cell line were apigenin 6,8-di-C-glucoside $\left(R^{2}=0.8294\right)$, methyleriodictyol-O-pentosylhexoside $\left(R^{2}=0.7416\right)$, luteolin-7-O-glucoside $\left(R^{2}=0.7708\right)$ and eriodictyol $\left(R^{2}=0.9235\right)$, while the phenolic acids were caffeic acid hexoside $\left(R^{2}=0.9226\right.$, for HeLA), caffeic acid $\left(R^{2}=0.5037\right.$, for HeLA), rosmarinic acid hexoside $\left(R^{2}=0.7211\right.$ and 0.5939 , for HeLA and HepG2, respectively), rosmarinic acid $\left(R^{2}=0.5748\right.$, for HepG2) and caffeic acid trimer $\left(R^{2}=0.8894\right.$ and 0.5696 , for HeLA and HepG2, respectively). In relation to peppermint extracts an opposite effect was observed in relation to thyme, being $\mathrm{NCI}$ $\mathrm{H} 460$ cell line correlated with the total phenolic acids $\left(R^{2}=0.5319\right)$, while HeLa and HepG2 cell lines were correlated with total flavonoids $\left(R^{2}=0.6946\right.$ and 0.6214 , respectively). The individual compounds that were responsible for these correlations were caffeic acid trimer $\left(R^{2}=0.5246\right.$, for $\left.\mathrm{NCI}-\mathrm{H} 460\right)$, rosmarinic acid $\left(R^{2}=0.5917\right.$, for NCI-H460), luteolin-O-diglucuronide $\left(R^{2}=0.4148\right.$ and 0.6462 , for HeLA and HepG2, respectively), eriodictyol-Orutinoside $\left(R^{2}=0.4075\right.$ and 0.6986 , for HeLA and HepG2, respectively), luteolin-7-O-rutinoside $\left(R^{2}=0.6409\right.$ and 0.5638 , for HeLA and HepG2, respectively) and luteolin-7-O-glucuronide $\left(R^{2}=0.4207\right.$ and 0.7956 , for HeLA and HepG2, respectively). Most of the mentioned phenolic compounds were not the main molecules present in the sample, meaning that synergistic effects are probably observed between the compounds, in order to enhance these activities.

Overall, all samples showed cytotoxic properties in human tumor cell lines, but with no toxicity for non-tumor cells. The different irradiation doses did not affect these properties or the phenolic composition of the peppermint samples. However, thyme samples irradiated at $10 \mathrm{kGy}$ showed higher cytotoxicity for tumor cell lines in comparison with the other doses applied. Therefore, for the studied species, it is confirmed that $10 \mathrm{kGy}$ can be applied because it did not affect the bioactive properties of these plants. The studied plants can represent a rich source of antioxidant compounds of phenolic nature: flavonols, flavones, flavanones and phenolic acid derivatives, which might contribute to the prevention and control of diseases through their incorporation into a normal diet or as supplements. Therefore, irradiation can be considered as a decontamination and preservation process (as described and tested by other authors), because when analysing the influence of this technology in compounds that provide the bioactive potential, it was found that it can be applied up to the maximum dose recommended in legislation (10 kGy) because it does not affect their concentration. This technology represents an added-value solution to meet the requirements of the food and pharmaceutical industries in the acquisition of high quality raw materials.

\section{Acknowledgements}

The authors are grateful to Foundation for Science and Technology (FCT, Portugal) for financial support to CIMO (PEst-OE/AGR/ UI0690/2014), C C TN (RECI/AAG-TEC/0400/2012) R.C. Calhelha (SFRH/BPD/BPD/68344/2010) and L. Barros (SFRH/BPD/107855/ 2015). The authors are also grateful to Ministry of Agriculture, Portugal (Project AROMAP - PRODER/FEADER), for financial support of the work and E. Pereira and Andreia I. Pimenta grants, and to "MaisErvas - Aromáticas e Medicinais" company for providing the samples.

\section{References}

Areias, F. M., Valentão, P., Andrade, P. B., Ferreres, F., \& Seabra, R. M. (2001). Phenolic fingerprint of peppermint leaves. Food Chemistry, 73, 307-311.

ASTM, American Society for Testing and Materials. (1992). Practice for Using the Fricke Reference standard Dosimetry System, ASTM E1026. Annual Book of ASTM Standards, 12.02, Philadelphia, PA.

Bajpai, V. K., Agrawal, P., Bang, B. H., \& Park, Y.-H. (2015). Phytochemical analysis, antioxidant and antilipid peroxidation effects of a medicinal plant, Adhatoda vasica. Frontiers in Life Science, 8, 305-312.

Barros, L., Pereira, E., Calhelha, R. C., Duenas, M., Carvalho, A. M., Santos-Buelga, C., et al. (2013). Bioactivity and chemical characterization in hydrophilic and lipophilic compounds of Chenopolium ambrosioides L. Journal of Functional Foods, 5, 1732-1740.

Berdowska, I., Zieliński, B., Fecka, I., Kulbacka, J., Saczko, J., \& Gamian, A. (2013). Cytotoxic impact of phenolics from Lamiaceae species on human breast cancer cells. Food Chemistry, 141, 1313-1321.

Boros, B., Jakabová, S., Dörnyei, Á., Horváth, G., Pluhár, Z., Kilár, F., et al. (2010). Determination of polyphenolic compounds by liquid chromatography-mass 
spectrometry in Thymus species. Journal of Chromatography A, 1217, 7972-7980.

Clifford, M. N., Johnston, K. L. Knight, S., \& Kuhnert, N. A. (2003). A hierarchica scheme for LC-MSn identification of chlorogenic acids. Journal of Agricultural and Food Chemistry, 51, 2900-2911.

Costa, P., Gonçalves, S., Valentão, P., Andrade, P. B., Coelho, N., \& Romano, A. (2012) Thymus lotocephalus wild plants and in vitro cultures produce different profiles of phenolic compounds with antioxidant activity. Food Chemistry, 135, 1253-1260.

Dapkevicius, A., van Beek, T. A., Lelyveld, G. P., van Veldhuizen, A., de Groot, A, Linssen, J. P., et al. (2002). Isolation and structure elucidation of radical scavengers from Thymus vulgaris leaves. Journal of Natural Products, 65, 892-896.

Dillard, C. J., \& German, G. B. (2000). Review phytochemicals: nutraceuticals and human health. Journal of the Science of Food and Agriculture, 80, 1744-1756.

Fachini-Queiroz, F. C., Kummer, R., Estevão-Silva, C. F., Carvalho, M. D. B., Cunha, J. M., Grespan, R., et al. (2012). Effects of thymol and carvacrol, constituents of Thymus vulgaris $L$. Essential oil, on the inflammatory response. Evidence-Based Complementary and Alternative Medicine, 2012, 1-10. Article ID 657026.

Fecka, I., \& Turek, S. (2008). Determination of polyphenolic compounds in commercial herbal drugs and spices from Lamiaceae: thyme, wild thyme and sweet marjoram by chromatographic techniques. Food Chemistry, 108, 1039-1053.

Gavarić, N., Kladara, N., Misanb, A., Nikolicc, A., Samojlikd, I., Mimica-Dukice, N. et al. (2015). Postdistillation waste material of thyme (Thymus vulgaris L., Lamiaceae) as a potential source of biologically active compounds. Industrial Crops and Products, 74, 457-464.

Grigoleit, H.-G., \& Grigoleit, P. (2005). Peppermint oil in irritable bowel syndrome. Phytomedicine, 12, 601-606.

Guimarães, R., Barros, L., Dueñas, M., Calhelha, R. C., Carvalho, A. M., SantosBuelga, C., et al. (2013). Infusion and decoction of wild German chamomile: bioactivity and characterization of organic acids and phenolic compounds. Food Chemistry, 136, 947-954.

Haleem, R. M., Salem, M. Y., Fatahallah, F. A., \& Abdelfattah, L. E. (2015). Quality in the pharmaceutical industry - a literature review. Saudi Pharmaceutical Journal, 23, 463-469.

Hossain, M. B., Rai, D. K., Brunton, N. P., Martin-Diana, A. B., \& Barry-ryan, C. (2010). Characterization of phenolic composition in Lamiaceae spices by LC-ESI-MS/MS Journal of Agricultural and Food Chemistry, 58, 10576-10581.

Jabri-Karoui, I., Bettaieb, I., Msaada, K., Hammami, M., \& Marzouk, B. (2012). Research on the phenolic compounds and antioxidante activities of Tunisian Thymus capitatus. Journal of Functional Foods, 4, 661-669.

Jain, S., Jain, A., Jain, N., Jain, D. K., \& Balekar, N. (2010). Phytochemical investigation and evaluation of in vitro free radical scavenging activity of Tabernaemontana divaricata Linn. Natural Product Research, 24, 300-304.

Kapp, K., Hakala, E., Orav, A., Pohjala, L., Vuorela, P., Püssa, T., et al. (2013). Commercial peppermint (Mentha $\times$ piperita L.) teas: antichlamydial effect and polyphenolic composition. Food Research International, 53, 758-766.

Krzyzanowska, J., Janda, B., Pecio, L., Stochmal, A., \& Oleszek, W. (2011). Determination of polyphenols in Mentha longifolia and M. piperita field-grown and in vitro plant samples using UPLC-TQ-MS. Journal of AOAC International, 94, 43-50.

Kume, T., Furuta, M., Todoriki, S., Uenoyama, N., \& Kobayashi, Y. (2009). Status of food irradiation in the world. Radiation Physics and Chemistry, 78, 222-226.

Lv, J., Huang, H., Yua, L., Whent, M., Niu, Y., Shi, H., et al. (2012). Phenolic composition and nutraceutical properties of organic and conventional cinnamon and peppermint. Food Chemistry, 132, 1442-1450.

Machhour, H., Hadrami, I. E., Imziln, B., Mouhib, M., \& Mahrouz, M. (2011). Microbia decontamination by low dose gamma irradiation and its impact on the physicochemical quality of peppermint (Mentha piperita). Radiation Physics and Chemistry, 80, 604-607.

Martins, N., Barros, L., Santos-Buelga, C., Silva, S., Henriques, M., \& Ferreira, I. C. F. R. (2015). Decoction, infusion and hydroalcoholic extract of cultivated thyme: antioxidant and antibacterial activities, and phenolic characterisation. Food
Chemistry, 167, 131-137.

McKay, D. L., \& Blumberg, J. (2006). A review of the bioactivity and potential health benefits of peppermint tea (Mentha piperita L.). Phytotherapy Research, 20, 619-633.

Mizani, M., Sheikh, N., Ebrahimi, S. N., Gerami, A., \& Tavakoli, F. A. (2009). Effect of gamma irradiation on physico-mechanical properties of spice packaging films. Radiation Physics and Chemistry, 78, 806-809.

Moghaddam, M., Pourbaige, M., Tabar, H. K., Farhadi, N., \& Hosseini, S. M. A. (2013). Composition and antifungal activity of peppermint (Mentha piperita) essential oil from Iran. Journal of Essential Oil Bearing Plants, 16, 506-512.

Nagy, T. O., Solar, S., Sontag, G., \& Koenig, J. (2011). Identification of phenolic components in dried spices and influence of irradiation. Food Chemistry, 128, $530-534$.

Nikolić, M., Glamočlija, J., Ferreira, I. C. F. R., Calhelha, R. C., Fernandes, Â., Markovićc, T., et al. (2014). Chemical composition, antimicrobial, antioxidant and antitumor activity of Thymus serpyllum L., Thymus algeriensis Boiss. and Reut and Thymus vulgaris L. essential oils. Industrial Crops and Products, 52, 183-190.

Pereira, E., Antonio, A. L., Barreira, J. C. M., Barros, L., Bento, A., \& Ferreira, I. C. F. R. (2015a). Gamma irradiation as a practical alternative to preserve the chemical and bioactive wholesomeness of widely used aromatic plants. Food Research International, 67, 338-348.

Pereira, E., Barrosa, L., Dueñas, M., Antonio, A. L., Santos-Buelga, C., \& Ferreira, I. C. F. R. (2015b). Gamma irradiation improves the extractability of phenolic compounds in Ginkgo biloba L. Industrial Crops and Products, 74, $144-149$.

Pérez, M. G. F. Rocha-Guzmán, N. E., Mercado-Silva, E., Loarca-Piña, G., \& ReynosoCamacho, R. (2014). Effect of chemical elicitors on peppermint (Mentha piperita) plants and their impact on the metabolite profile and antioxidant capacity of resulting infusions. Food Chemistry, 156, 273-278.

Riachi, L. G., \& De Maria, C. A. B. (2015). Peppermint antioxidants revisited. Food Chemistry, 176, 72-81.

Roby, M. H. H., Sarhan, M. A., Selim, K. A.-H., \& Khalel, K. I. (2013). Evaluation of antioxidant activity, total phenols and phenolic compounds in thyme (Thymus vulgaris L.), sage (Salvia officinalis L.), and marjoram (Origanum majorana L.) extracts. Industrial Crops and Products, 43, 827-831.

Sadeckà, J. (2007). Irradiation of spices - a review. Czech Journal of Food Science, 25, $231-242$.

Sharma, M., \& Sharma, M. (2013). Antimicrobial potential of essential oil from Mentha piperita L. against anthropophilic dermatophytes. Journal of Essential Oil Bearing Plants, 15, 263-269.

Singh, R., Shushni, M. A. M., \& Belkheir, A. (2015). Antibacterial and antioxidant activities of Mentha piperita L. Arabian Journal of Chemistry, 8, 322-328.

Tezotto-Uliana, J. V., Silva, P. P. M., Kluge, R. A., \& Spoto, M. H. F. (2015). Radiação Gama em Produtos de Origem Vegetal. Revista Virtual de Ouímica, 7, 267-277.

Vallverdú-Queralt, A., Regueiro, J., Martínez-Huélamo, M., Alvarenga, J. F. R., Leal, L. N., \& Lamuela-Raventos, M. (2014). Comprehensive study on the phenolic profile of widely used culinary herbs and spices: rosemary, thyme, oregano, cinnamon, cumin and bay. Food Chemistry, 154, 299-307.

Vergara-Salinas, J. R., Perez-Jimenez, J., Torres, J. L., Agosin, E., \& Perez-Correa, J. R. (2012). Effects of temperature and time on polyphenolic content and antioxidant activity in the pressurized hot water extraction of deodorized thyme (Thymus vulgaris). Journal of Agricultural and Food Chemistry, 60, 10920-10929.

Wojdyło, A., Oszmiański, J., \& Czemerys, R. (2007). Antioxidant activity and phenolic compounds in 32 selected herbs. Food Chemistry, 105, 940-949.

Zgórka, G., \& Głowniak, K. (2001). Variation of free phenolic acids in medicinal plants belonging to the Lamiaceae family. Journal of Pharmaceutical and Biomedical Analysis, 26, 79-87.

Zhang, J.-Y., Wang, Y.-Z., Zhao, Y.-L., Yang, S.-B., Zuo, Z.-T., Yang, M.-Q., et al. (2011). Phytochemicals and bioactivities of Paris species. Journal of Asian Natural Products Research, 13, 670-681. 